Asian J Agric \& Biol. 2021(3).

\title{
Application of partial gelatinization autoclaving-cooling process to increase the resistant starch content of fermented cassava pulp flour-based composite flour
}

\author{
Beni Hidayat 1,3*, Udin Hasanudin², Siti Nurdjanah², Neti Yuliana², Syamsu Akmal ${ }^{3}$, M. Muslihudin ${ }^{3}$ \\ ${ }^{1}$ Doctorate Program, Agriculture Science, University of Lampung, Lampung, Indonesia \\ ${ }^{2}$ Agricultural Product Technology Department, Faculty of Agriculture, University of Lampung, Lampung, Indonesia \\ ${ }^{3}$ Agricultural Technology Department, Politeknik Negeri Lampung, Lampung, Indonesia
}

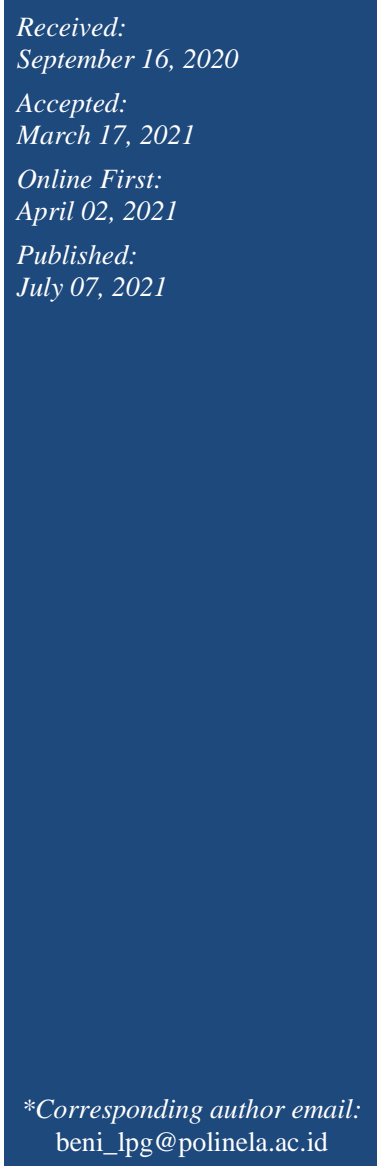

\begin{abstract}
Fermented cassava pulp flour-based composite flour (FCPF-based composite flour) is a composite flour consisting of fermented cassava pulp flour, cassava starch, and xanthan gum which has the potential to be developed as a gluten free flour. This study was aimed to increase the resistant starch (RS) content of FCBF-based composite flour through the application of the partial gelatinization (PG) autoclaving-cooling process. Other aims were to characterize its chemicals properties, granular morphology, polarized optical microscopy, amylographic profile, X-ray diffraction pattern and relative crystallinity, degree of starch hydrolysis and estimated glycemic index (EGI). The results of the study revealed that PG autoclaving for $15 \mathrm{~min}$ and cooling time $72 \mathrm{~h}$ was the optimal treatments that increased the RS content of FCPF-based composite flour from $1.75 \%$ to $7.31 \%$. This study indicated that the increasing of resistant starch content of FCPF-based composite flour changed its chemicals properties, granular morphology, polarized optical microscopy, amylographic profile, X-ray diffraction pattern and relative crystallinity; and lowering the degree of starch hydrolysis and value of estimated glycemic index (EGI). Increased the RS content would improve the functional properties of FCPF-based composite flour.
\end{abstract}

Keywords: Resistant starch, Fermented cassava pulp, Composite flour, Gluten-free flour

\section{How to cite this:}

Hidayat B, Hasanudin U, Nurdjanah S, Yuliana N, Akmal S and Muslihudin M, 2021. Application of partial gelatinization autoclaving-cooling process to increase the resistant starch content of fermented cassava pulp flour-based composite flour. Asian J. Agric. Biol. 2021(3): 202009483. DOI: https://doi.org/10.35495/ajab.2020.09.483

This is an Open Access article distributed under the terms of the Creative Commons Attribution 3.0 License. (https://creativecommons.org/licenses/by/3.0), which permits unrestricted use, distribution, and reproduction in any medium, provided the original work is properly cited.

\section{Introduction}

Resistant starch (RS) is a starch fraction and starch degradation products that are not absorbed in the small intestine of human (Englyst et al., 1992) and has beneficial physiological effects such as of dietary fiber
(Fuentes-Zaragoza et al., 2011). The content of resistant starch has a linear correlation with the glycemic index (GI) of starchy foods (Yamada et al., 2005; Ashraf et al., 2012). The increase of RS content on food is potential to be carried out considering that RS does not cause changes in food quality (Alsaffar, 
2011). Compared with fruktooligosakarida (FOS) and inulin, RS can bind and maintain water content in the faeces, so that it does not cause constipation and flatulence if consumed in large quantities (Ozturk et al., 2011; Vatanasuchart et al., 2012). Resistant starch (RS) is categorized as RS type 1 (RS1) to RS type 5 (RS5). Processing method which utilizes heat and moisture has been reported increased the content of RS-3 in a typical food product (Fuentes-Zaragoza et al., 2011).

One of the food products whose RS content has the potential to be increased is composite flour based on fermented cassava pulp flour (FCPF-based composite flour). FCPF-based composite flour is a composite flour consisting of a mixture of fermented cassava pulp flour, cassava starch and xanthan gum which has the potential to be developed as a gluten-free composite flour (Hidayat et al., 2020). The addition of cassava starch and hydrocolloid in the form of xanthan gum will improve the functional characteristics and the pasting properties of fermented cassava pulp flour. Xanthan gum is a hydrophilic biopolymer so it dissolves easily in cold and hot water and acts as a food emulsifier/stabilizer (Garcia-Ochoa et al., 2000). FCPF-based composite flour can be categorized as gluten-free flour as it containt high in protein $(4.24 \%)$ and dietary fiber (16.53\%) (Hidayat et al., 2020). In addition, the development of FCPF-based composite flour is also an effort to increase the economic value of cassava pulp, by-product of cassava starch industries. FCPF-based composite flour with high in RS content is a good functional food and potential to be used as gluten-free flour.

The increase of RS content of cassava products is generally carried out in the form of cassava starch (Vatanasuchart et al., 2010; Abioye et al., 2017; Abioye et al., 2018). Autoclaving-cooling method with several cycles is commonly used to increase the RS content of starch (Abioye et al., 2018; Dundar and Gocmen, 2013; Zheng et al., 2020) and RS3 is formed through a retrogradation process. Autoclaving will induce starch gelatinization throughout the stages of swelling, amylose leaching, partial granule disruption, and formation of a starch paste. Cooling will facilitate the retrograde of disaggregated starch chains (Wang et al., 2015).

However, this method has several drawbacks such as requirement of starch extraction stage and separation of other nutritional components, difficulty of to dry the starch as autoclaving cooling process might gelatinize the starch and prone to damage the starch during drying (Zheng et al., 2020). To eliminate the stage of starch extraction and simplify the drying process, increasing the RS content can be done directly from its flour (Chen et al., 2015) and use of autoclaving with the partial gelatinization method (Chung et al., 2006; Chen et al., 2015). This partial gelatinization condition can be carried out through limiting the moisture content by high moisture treatment (HMT) or using a temperature below the gelatinization point (annealing) so that complete gelatinization does not occur. Chen et al. (2015), reported that the HMT process followed by cooling increased the RS content of wheat flour from $1.09 \%$ to $13.28 \%$. Those findings support the idea that RS content of FCBF-based composite flour which has a starch content of $67.14 \%$ (db) can be increased through the autoclaving process on partial gelatinization condition (PG autoclaving) followed by a cooling process which will stimulate the formation of RS 3 through the retrogradation process. In addition to increasing the RS content, the application of the HMT and cooling process will also change the crystal structure and patterns, polarized optical microscopy properties, pasting properties and in vitro starch digestibility of wheat flour (Chen et al., 2015). Therefore, this study was aimed to increase the RS content of FCBF-based composite flour through the application of the PG (partial gelatinization) autoclaving-cooling process. Other aims were to characterize its chemicals properties, granular morphology, polarized optical microscopy, amylographic profile, X-ray diffraction pattern and relative crystallinity, degree of starch hydrolysis as well as estimated glycemic index (EGI).

\section{Material and Methods}

\section{Material and chemicals}

Cassava var. Kasetsart was obtained from cassava farmers in Margomulyo Village, Jati Agung District, South Lampung Districts, Indonesia, harvested nine months after planting. Pure culture of $S$. cerevisiae was purchased from the culture collection of microbiology laboratory of Bogor Agricultural University. Xanthan gum (Sigma-Aldrich G-12530), alpha-amylase (Sigma-Aldrich A-4862), pepsin (Sigma-Aldrich P-7000), amyloglucosidase (Supelco A-9913) obtained by PT Laborindo Sarana, Jakarta; cassava starch was obtained from PD Semangat Jaya, Pesawaran, Lampung; Megazyme Resistant Starch Kit and Megazyme Amylose/Amylopectin Kit (Megazyme Bray Business Park, Bray, Co. Wicklow, 
Ireland) were obtained from PT Indogen Intertama, Jakarta.

\section{Preparation of fermented cassava pulp flour}

Preparation of fermented cassava pulp flour was carried out according to the method of Hidayat et al. (2019) included the stages of preparing a pure culture of $S$. cerevisiae, preparation of fresh cassava pulp, fermentation process for 3 days under aerobic conditions, drying and milling. The chemical composition of fermented cassava pulp flour is presented in Table 1.

\section{Preparation of composite flour}

Preparation of FCPF-based composite flour was carried out by mixing evenly of the fermented cassava pulp flour and cassava starch with a ratio of $80 \%: 20 \%$ (100\% total flour) and $0.1 \%$ of xanthan gum (Hidayat et al., 2020). The chemical composition of FCPFbased composite flour is presented in Table 1.

Table-1. Chemical composition of fermented cassava pulp flour and FCPF-based composite flour (mean \pm SD, $n=3$ )

\begin{tabular}{|l|c|c|}
\hline \multicolumn{1}{|c|}{ Component } & $\begin{array}{c}\text { Fermented } \\
\text { cassava pulp } \\
\text { flour }\end{array}$ & $\begin{array}{c}\text { FCPF-based } \\
\text { composite flour }\end{array}$ \\
\hline Water (\%) & $10.23 \pm 0.99$ & $9.41 \pm 0.85$ \\
\hline Ash (\%) & $0.12 \pm 0.07$ & $0.09 \pm 0.03$ \\
\hline Carbohydrate (\%) & $82.23 \pm 1.60$ & $85.41 \pm 1.18$ \\
\hline Starch (\%) & $57.18 \pm 2.82$ & $67.14 \pm 2.00$ \\
\hline Dietary fiber (\%) & $22.04 \pm 1.87$ & $16.53 \pm 1.41$ \\
\hline Protein (\%) & $6.19 \pm 0.57$ & $4.24 \pm 0.11$ \\
\hline Lipid (\%) & $1.13 \pm 0.11$ & $0.85 \pm 0.22$ \\
\hline Cyanide (ppm) & $8.91 \pm 1.38$ & $6.73 \pm 0.98$ \\
\hline
\end{tabular}

\section{Methodology of increasing the RS content of FCPF-based composite flour}

The increasing process of RS content was carried out by the partial gelatinization method using autoclaving at $121^{\circ} \mathrm{C}$ (PG autoclaving) and cooling at $4^{\circ} \mathrm{C}$ for two cycles. Water $(20 \%)$ was added to the composite flour and stirred continuously. The pressurized heating was then carried out using an autoclave according to treatment (15 $\mathrm{min}$ and $30 \mathrm{~min}$ ) followed by cooling according to treatment $(24,48$, and $72 \mathrm{~h})$. The same process of heating and cooling was repeated for second cycle. The sample then dried using a cabinet dryer at $50^{\circ} \mathrm{C}$ for $5-6$ hours followed by grinding until 80 mesh using a hammer mill to obtain high RS content of FCPF-based composite flour:

\section{Analysis of chemical properties}

The RS, Non-RS, and amylose/amylopectin contents of the FCPF-based composite flour sampels were measured using the Megazyme Resistant Starch Kit and the Megazyme Amylose/Amylopectin Kit (Megazyme Bray Business Park, Bray, Co. Wicklow, Ireland) according to the Approved Method 32-40 (AACCI, 2010). Total starch content is the sum of resistant starch and non-resistant (solubilised) starch. The procedure of the analysis was a modification of Con A methods developed by Yun and Matheson (1990). The analysis of chemical properties was carried out in three replicates and the data obtained were reported as mean $\pm \mathrm{SD}$.

\section{Analysis of granular morphology}

Analysis of granular morphology of FCPF-based composite flour was conducted with the Scanning Electron Microscope (SEM) method using SEM ZEISS EVO MA 10 at a magnification of 1000x. The surface of the sample was coated with a thin layer of gold under a sputtering time of $60 \mathrm{~s}$ and a sputtering current of $20 \mathrm{~mA}$. The sample was inserted into the SEM device and surface images were taken using a Secondary Electron (SE) detector; working distance (WD) $9-9.5 \mathrm{~mm}$; EHT $15 \mathrm{kV}$.

\section{Analysis of polarized optical microscopy}

Analysis of polarized optical microscopy of FCPFbased composite flour was performed using an Olympus BX-51 light microscope (Tokyo, Japan) with a bright field and polarized light. The sample powder was sprinkled on a glass slide and covered with a drop of aqueous glycerol solution (1: 1 water/glycerin). The dispersed sample was covered with a cover glass. The image was recorded at a magnification of 400x.

\section{Analysis of X-ray diffraction pattern and relative crystallinity}

X-ray diffraction pattern and relative crystallinity of FCPF-based composite flour were analyzed using XRay Diffraction based on the method of Vermeylen et al. (2006). Measurements were made in the range of 2Ө: $5-45^{\circ}$ at $40 \mathrm{kV}, 30 \mathrm{~mA}$ and speed of $2^{\circ}$ per min. The analysis was carried out in three replicates and the data obtained were reported as mean \pm SD. Relative crystallinity was calculated using the curve fitting method (Ahvenainen and Svedstrom, 2016), using the following equation 
Relative crystallinity $(\%)=\frac{\text { The area of crystalline regions }}{\text { Total area }(\text { crystalline+amorphous regions })} \times 100$

\section{Analysis of amylographic profile}

Analysis of amylographic profile of FCPF-based composite flour was carried out using brabender viscograph type Brabender $\mathrm{GmbH} \& \mathrm{Co}$. KG, Germany. The sample suspension $(6.0 \%)$ was put into the amylograph bowl, then rotated in 30-35 rotations per min while temperature was increased from $50^{\circ} \mathrm{C}$ to $92^{\circ} \mathrm{C}$ with a temperature increase rate of $1.5^{\circ} \mathrm{C} / \mathrm{min}$. The temperature was maintained at $92^{\circ} \mathrm{C}$ for $15 \mathrm{~min}$, then lowered to $50^{\circ} \mathrm{C}$ at a rate of $1.5^{\circ} \mathrm{C} / \mathrm{min}$ and maintained for $10 \mathrm{~min}$. Changes in paste viscosity were recorded continuously by the brabender viscograph on graph paper. Observations were made on the peak viscosity (PV), breakdown viscosity (BV), final viscosity (FV), setback (SB), peak time (PT) and peak temperature (P.temp) (Dundar and Gocmen, 2013). The analysis of amylographic profile was carried out in three replicates and the data obtained were reported as mean \pm SD.

\section{Degree of starch hydrolysis and estimated glycemic index (EGI) analysis}

The degree of starch hydrolysis of FCPF-based composite flour samples was measured according to an established in vitro method by Goni et al. (1997). Glucose liberated during 30th to 180th $\min$ of enzymatic incubation was analyzed after interval 30 min and converted to the amount of hydrolyzed starch by multiplying with a factor of 0.9. Percentage of starch hydrolyzed during each interval was expressed as the degree of hydrolysis. FCPF-based composite flour without treatment was used as a control and white bread was used as the reference food. The analysis of the degree of starch hydrolysis was carried out in three replicates and the data obtained were reported as mean \pm SD.

The estimated glycemic index (EGI) value was determined based on the method of Goni et al. (1997) and Zheng et al. (2020) through the steps of drawn of starch hydrolysis curve using the percentage of starch hydrolysis as ordinate and the time as abscissa, calculating the value of the area under the curve
(AUC), calculating the value of HI (hydrolysis index) by comparing the AUC of samples and standard AUC (white bread) and convert HI values into EGI values. The HI and EGI were calculated using the following equations: $\mathrm{HI}=($ AUC sample/AUC white bread (reference food $)) \times 100$
$\mathrm{EGI}=39.71+(0.549 \times \mathrm{HI})$

\section{Experimental design and statistical analysis}

The experiment was conducted using a completely randomized design (CRD) with 2 factors. The first factor is several PG-autoclaving time (15 dan $30 \mathrm{~min}$ ). The second factor is several autoclaving time $(24,48$, $72 \mathrm{~h}$ ). The FCPF-based composite flour without treatment was used as control.

The data of chemical properties, relative crystallinity, amylographic profile and degree of starch hydrolysis were analyzed by one-way analysis of variance (ANOVA) using SPSS 16.0 software and continued with the least significant difference (LSD) test. The significance of the differences was defined as $\mathrm{P}<0.05$.

\section{Results and Discussion}

\section{RS, Non-RS, and total starch content}

RS, non-RS, and total starch content of FCPF-based composite flour on various PG autoclaving and cooling time are presented in Table 2.

The application of the PG autoclaving and cooling process significantly $(\mathrm{P}<0.05)$ would increase the RS content of FCPF-based composite flour. This showed that the application of the PG autoclaving method would increase the RS content of FCPF-based composite flour even though the autoclaving process was not carried out in perfect gelatinization conditions. A similar phenomenon was also reported by Chen et al. (2015) that showed the PG method was able to increase the content of RS wheat flour from $1.09 \%$ to $13.28 \%$. Increasing the RS content in the form of flour has the advantage of not requiring a starch extraction stage, while the use of the PG method make the drying process becomes easier and the remained the pasting properties of produced flour. 
Table-2. Resistant starch (RS), non-resistant starch (non-RS), total starch (TS) of FCPF-based composite flour on various level of $P G$ autoclaving and cooling time (mean \pm SD, \% dry basis)

\begin{tabular}{|c|c|c|c|c|}
\hline Treatment & RS (\%) & $\begin{array}{c}\text { Non-RS } \\
(\%)\end{array}$ & TS (\%) & $\begin{array}{c}\text { amylose } \\
(\%)\end{array}$ \\
\hline Without treatment & $\begin{array}{c}1.75 \pm \\
0.16^{\mathrm{f}}\end{array}$ & $\begin{array}{c}72.36 \pm \\
0.56^{\mathrm{a}}\end{array}$ & $\begin{array}{c}74.11 \pm \\
0.33^{\mathrm{a}}\end{array}$ & $\begin{array}{c}20.57 \pm \\
0.90^{\mathrm{a}}\end{array}$ \\
\hline $\begin{array}{l}\text { PG autoclaving } 15 \\
\text { min, cooling } 24 \mathrm{~h}\end{array}$ & $\begin{array}{c}2.41 \pm \\
0.16^{\mathrm{e}}\end{array}$ & $\begin{array}{c}71.90 \pm \\
1.85^{\mathrm{ab}}\end{array}$ & $\begin{array}{c}74.31 \pm \\
1.38^{\mathrm{a}}\end{array}$ & $\begin{array}{c}21.47 \pm \\
2.43^{\mathrm{a}}\end{array}$ \\
\hline $\begin{array}{l}\text { PG autoclaving } 15 \\
\text { min, cooling } 48 \mathrm{~h}\end{array}$ & $\begin{array}{l}5.13 \pm \\
0.22^{\mathrm{b}}\end{array}$ & $\begin{array}{c}68.93 \pm \\
2.30^{\mathrm{bc}}\end{array}$ & $\begin{array}{c}74.06 \pm \\
2.03^{\mathrm{a}}\end{array}$ & $\begin{array}{l}21.58 \pm \\
1.49^{\mathrm{a}}\end{array}$ \\
\hline $\begin{array}{l}\text { PG autoclaving } 15 \\
\text { min, cooling } 72 \mathrm{~h}\end{array}$ & $\begin{array}{c}7.31 \pm \\
0.39^{\mathrm{a}}\end{array}$ & $\begin{array}{c}65.77 \pm \\
2.44^{\mathrm{c}}\end{array}$ & $\begin{array}{c}73.08 \pm \\
1.68^{\mathrm{a}}\end{array}$ & $\begin{array}{c}20.14 \pm \\
0.84^{\mathrm{a}}\end{array}$ \\
\hline $\begin{array}{l}\text { PG autoclaving } 30 \\
\text { min, cooling } 24 \mathrm{~h}\end{array}$ & $\begin{array}{r}4.17 \pm \\
0.39^{\mathrm{d}}\end{array}$ & $\begin{array}{c}68.17 \pm \\
0.87^{\mathrm{c}}\end{array}$ & $\begin{array}{c}72.34 \pm \\
0.59^{\mathrm{a}}\end{array}$ & $\begin{array}{c}20.04 \pm \\
0.93^{\mathrm{a}}\end{array}$ \\
\hline $\begin{array}{l}\text { PG autoclaving } 30 \\
\text { min, cooling } 48 \mathrm{~h}\end{array}$ & $\begin{array}{l}4.50 \pm \\
0.23^{\mathrm{cd}}\end{array}$ & $\begin{array}{c}68.86 \pm \\
1.69^{\mathrm{bc}}\end{array}$ & $\begin{array}{c}73.36 \pm \\
1.53^{\mathrm{a}}\end{array}$ & $\begin{array}{c}20.09 \pm \\
0.73^{\mathrm{a}}\end{array}$ \\
\hline $\begin{array}{l}\text { PG autoclaving } 30 \\
\text { min, cooling } 72 \mathrm{~h}\end{array}$ & $\begin{array}{l}4.70 \pm \\
0.22^{\mathrm{bc}}\end{array}$ & $\begin{array}{c}68.79 \pm \\
1.98^{\mathrm{bc}}\end{array}$ & $\begin{array}{c}73.49 \pm \\
1.47^{\mathrm{a}}\end{array}$ & $\begin{array}{c}20.92 \pm \\
1.26^{\mathrm{a}}\end{array}$ \\
\hline
\end{tabular}

Values with the different superscript letters at the same column are significantly different $(\mathrm{P}<0.05)$

The highest content of RS (7.31\%) was obtained in 15 min of PG autoclaving treatment and $72 \mathrm{~h}$ of cooling time (Table 2). As can be seen in Table 2, at the same cooling time of $72 \mathrm{~h}$, higher content of RS in the autoclaving time of $15 \mathrm{~min}(7.31 \%)$ compared to 30 $\min (4.7 \%)$ indicates the optimal time is required for PG autoclaving treatment to produce composite flour with high RS content. Long during of $\mathrm{PG}$ autoclaving process increased the degree of gelatinization which produced amylose with a low degree of polymerization. Amylose with a low degree of polymerization will move too fast and complicate the formation of RS (Zheng et al., 2020).

Cooling time had more effect on increase of RS content than the duration of the autoclaving process (Table 2). Increasing the length of the cooling process from $24 \mathrm{~h}$ to 72 hon $15 \mathrm{~min}$ PG autoclaving treatment increased the RS content from $5.13 \%$ to $7.31 \%$. RS content increased with cooling time, especially related to duration of retrogradation process (Dundar and Gocmen, 2013). The longer the cooling process, the more intensive of retrogradation process and the higher the RS content.

The higher the RS content, the lower the Non-RS content (Table 2). while the autoclaving-cooling treatment does not affect $(\mathrm{P} \geq 0.05)$ on amylose content, as reported by Herawati et al. (2019) on the autoclaving-cooling process of tacca starch. This shows that there is no breaking of the amylose or amylopectin polymer chains during the PG autoclaving-cooling process.

\section{Granular morphology}

Granular morphology of FCPF-based composite flour on various $\mathrm{PG}$ autoclaving and cooling time are presented in Fig. 1. FCPF-based composite flour granule without treatment is round with a smooth outer surface containing a conical pit.

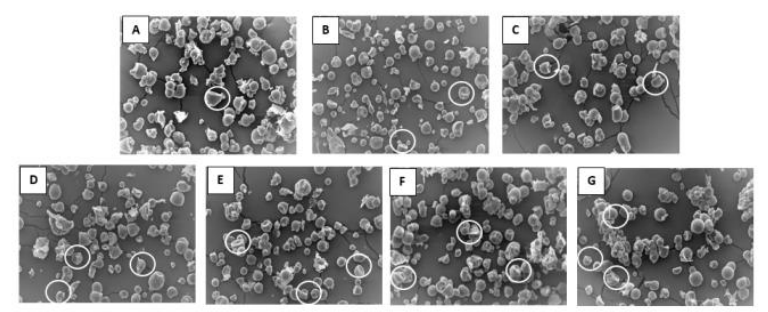

Figure-1. Granular morphology of FCPF-based composite flour on various PG-autoclaving and cooling time at magnification of $1.000 x$, the white round indicates starch granules with some dents and holes on the surface of the granule

$(\mathrm{A}=$ without treatment; $\mathrm{B}=\mathrm{PG}$ autoclaving $15 \mathrm{~min}$, cooling $24 \mathrm{~h} ; \mathrm{C}=\mathrm{PG}$ autoclaving $15 \mathrm{~min}$, cooling 48 $\mathrm{h} ; \mathrm{D}=\mathrm{PG}$ autoclaving $15 \mathrm{~min}$, cooling $72 \mathrm{~h} ; \mathrm{E}=\mathrm{PG}$ autoclaving $30 \mathrm{~min}$, cooling $24 \mathrm{~h} ; \mathrm{F}=\mathrm{PG}$ autoclaving $30 \mathrm{~min}$, cooling $48 \mathrm{~h} ; \mathrm{G}=\mathrm{PG}$ autoclaving $30 \mathrm{~min}$, cooling $72 \mathrm{~h}$ ).

According to Vatanasuchart et al. (2010), in general, cassava starch granules are a round or oval shape with a truncated end. The PG autoclaving-cooling treatment cause the starch granules to have some dents and holes on the surface of granule (white round mark in Fig. 1).This suggested that the PG autoclaving-cooling process did not cause the extreme granular structure changes and in line with the studies by Sun et al. (2014) on sorghum starch and sorghum flour and Putra et al. (2020) on tannia flour. However, this result was in contrast with the study on the autoclaving process for lotus seed (Zhang et al., 2014), chickpea starch (Polesi and Sarmento, 2011) and corn starch (Kim et al., 2010) where the original form of the granule structure disappears and a compact block structure was formed. The unchanging of the original granule structure on the application of the PG autoclaving-cooling process was mainly related to the imperfect gelatinization process that occurred. The imperfect gelatinization process does not cause the starch granules to change its structure and form a block structure. 


\section{Polarized optical microscopy}

The results of polarized optical microscopy analysis show that most of the starch granules of FCPF-based composite flour without treatment have birefringence properties, which divide the starch granules at their central point into light and dark areas (Fig. 2). According to Błaszczak et al. (2011), when the polarized light passes through the starch granules, differences in starch density and the refractive index cause birefringence, which appears as the polarization cross on the central point of starch granules.

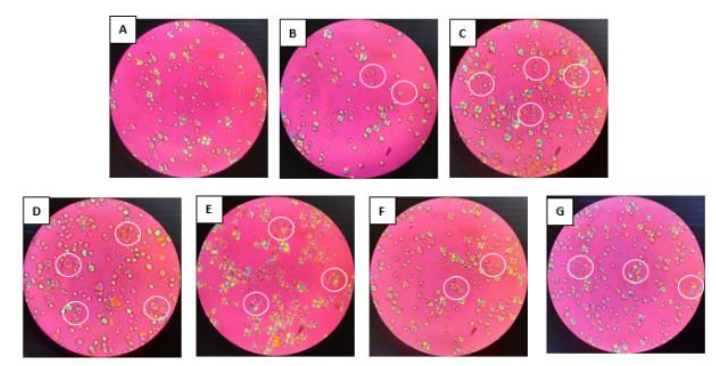

Figure-2. Polarized optical microscopy of FCPFbased composite flour on various PG-autoclaving and cooling time at magnification of $400 x$, the white round indicates starch granules that loss of polarization cross on the central point

$(\mathrm{A}=$ without treatment; $\mathrm{B}=\mathrm{PG}$ autoclaving $15 \mathrm{~min}$, cooling $24 \mathrm{~h} ; \mathrm{C}=\mathrm{PG}$ autoclaving $15 \mathrm{~min}$, cooling 48 $\mathrm{h} ; \mathrm{D}=\mathrm{PG}$ autoclaving $15 \mathrm{~min}$, cooling $72 \mathrm{~h} ; \mathrm{E}=\mathrm{PG}$ autoclaving $30 \mathrm{~min}$, cooling $24 \mathrm{~h} ; \mathrm{F}=\mathrm{PG}$ autoclaving $30 \mathrm{~min}$, cooling $48 \mathrm{~h} ; \mathrm{G}=\mathrm{PG}$ autoclaving $30 \mathrm{~min}$, cooling $72 \mathrm{~h}$ ).

The more intensive the PG autoclaving-cooling process, the higher the number of starch granules that lose their birefringence properties, which is indicated by the loss of polarization cross on the central point of starch granules (white round mark in Fig. 2). The loss of birefringence characteristics is mainly due to the damage to the starch crystalline structure (Zhang, et al., 2014). The damage of the starch crystalline structure is also in accordance with the results in Table 3 which show that the autoclaving-cooling treatment reduce the relative crystallinity of FCPF-based composite flour. The results also showed that some of the starch granules treated with PG autoclavingcooling had not lost their birefringence properties even though the cross patterns became increasingly fuzzier and disappear.
Chen et al. (2015) also found that PG treatment of $25 \%$ moisture content did not cause wheat flour to lose its overall birefringence properties.

X-ray diffraction pattern and relative crystallinity $\mathrm{X}$-ray diffraction pattern and relative crystallinity of FCPF-based composite flour on various PG autoclaving and cooling time are presented in Tabel 3 and Fig. 3. The application of the PG autoclaving and cooling process significantly $(\mathrm{P}<0.05)$ decreased the relative crystallinity of FCPF-based composite flour. The PG autoclaving-cooling process causes amylose liberation so that the starch granules were not intact and not compact.

Tabel-3. Relative crystallinity of FCPF-Based Composite Flour on various PG-autoclaving and cooling time

\begin{tabular}{|l|c|}
\hline \multicolumn{1}{|c|}{ Treatment } & Relative crystallinity (\%) \\
\hline Without treatment & $11.20 \pm 0.72^{\mathrm{a}}$ \\
\hline PG autoclaving $15 \mathrm{~min}$, cooling $24 \mathrm{~h}$ & $9.70 \pm 0.78^{\mathrm{bc}}$ \\
\hline PG autoclaving $15 \mathrm{~min}$, cooling $48 \mathrm{~h}$ & $9.81 \pm 0.54^{\mathrm{b}}$ \\
\hline PG autoclaving $15 \mathrm{~min}$, cooling $72 \mathrm{~h}$ & $9.72 \pm 0.44^{\mathrm{bc}}$ \\
\hline PG autoclaving $30 \mathrm{~min}$, cooling $24 \mathrm{~h}$ & $8.38 \pm 0.11^{\mathrm{d}}$ \\
\hline PG autoclaving 30 min, cooling 48 h & $8.72 \pm 0.04^{\mathrm{d}}$ \\
\hline PG autoclaving 30 min, cooling 72 h & $9.20 \pm 0.73^{\mathrm{bcd}}$ \\
\hline
\end{tabular}

Values with the different superscript letters at the same column are significantly different $(\mathrm{P}<0.05)$

This incomplete and incompatible starch condition lead to damage the crystalline structure, thereby reducing relative crystallinity. Decrease in relative crystallinity during the $\mathrm{PG}$ process was occured due to double-helical movements that disrupt starch crystallites and/or changed crystallite orientation (Gunaratne and Hoover, 2002). Similar results were reported by Chen et al. (2015), who found that the application of the $\mathrm{PG}$ process will reduce the relative crystallinity of wheat flour. The results of the analysis also showed that the autoclaving-cooling treatment does not change the X-ray diffraction peak of $2 \Theta$, namely $15^{\circ}, 17^{\circ}, 18^{\circ}$, and $23^{\circ}$ of FCPF-based composite flour, but change its intensity (Fig. 3) and relative crystallinity (Table 3 ). According to Zhang, et al. (2014) change in the intensity of X-ray diffraction peaks reflect changes in amorphous and crystalline regions. 


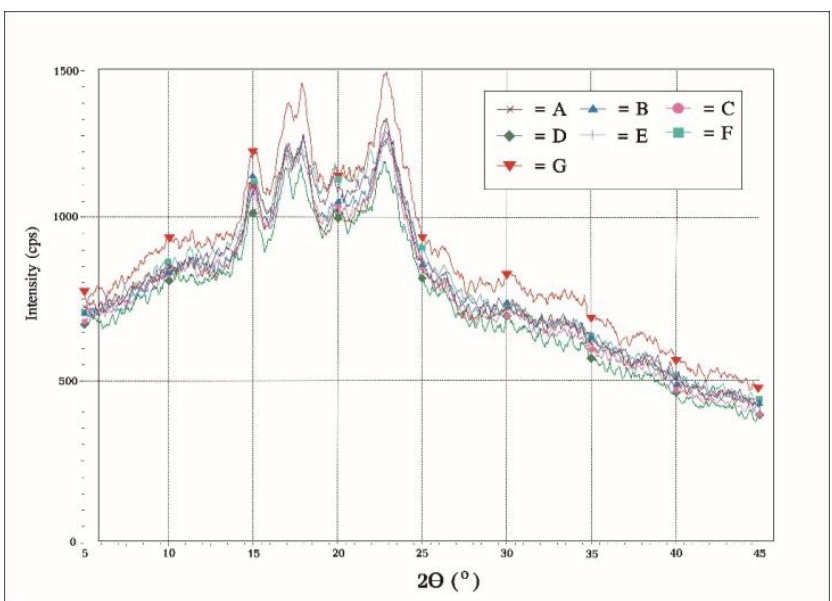

Figure-3. X-ray diffraction pattern of FCPFbased composite flour on various PG-autoclaving and cooling time

( $\mathrm{A}=$ without treatment; $\mathrm{B}=\mathrm{PG}$ autoclaving $15 \mathrm{~min}$, cooling $24 \mathrm{~h} ; \mathrm{C}=\mathrm{PG}$ autoclaving $15 \mathrm{~min}$, cooling 48 $\mathrm{h} ; \mathrm{D}=\mathrm{PG}$ autoclaving $15 \mathrm{~min}$, cooling $72 \mathrm{~h} ; \mathrm{E}=\mathrm{PG}$ autoclaving $30 \mathrm{~min}$, cooling $24 \mathrm{~h} ; \mathrm{F}=\mathrm{PG}$ autoclaving $30 \mathrm{~min}$, cooling $48 \mathrm{~h} ; \mathrm{G}=\mathrm{PG}$ autoclaving $30 \mathrm{~min}$, cooling $72 \mathrm{~h}$ ).

\section{Amylographic profile}

The amylographic profile of FCPF-based composite flour on various PG autoclaving and cooling time observed by the brabender method is presented in Table 4 and Fig. 4. The detection of an amylographic profile is an advantageous thing because it means that the FCPF-based composite flour which has been increased in RS content still has pasting properties like other native flours. Similar results were reported by Chen et al. (2015) on the properties of wheat flour pasting, which RS content is increased through a partial gelatinization process. The application of the PG autoclaving and cooling process significantly $(\mathrm{P}<0.05)$ cause changes in the viscosity profile but did not affect $(\mathrm{P} \geq 0.05)$ the gelatinization temperature profile of FCPF-based composite flour. The longer the PG autoclaving and cooling process, the lower the viscosity of FCPF-based composite flour. According to Dundar and Gocmen (2013), the decrease in viscosity is due to the disrupted starch granules and partial solubilization caused by high autoclaving temperature.

As can be seen in Fig. 4, the higher the intensity of the autoclaving-cooling treatment, the lower the value of peak viscosity (208 $\mathrm{BU}$ to $51 \mathrm{BU})$, trough viscosity (166 BU to $34 \mathrm{BU}$ ), breakdown viscosity (49 BU to 8 BU), final viscosity (208 BU to $51 \mathrm{BU}$ ) and setback viscosity (51 BU to $17 \mathrm{BU})$. Reduction in the viscosity profile of FCPF-based composite flour was mainly related to the increase in RS content due to the PG autoclaving-cooling treatment (Table 1).

Table-4. Amylographic profile of FCPF-based composite flour on various autoclaving and cooling time

\begin{tabular}{|l|c|c|c|c|c|c|c|}
\hline \multicolumn{1}{|c|}{ Treatment } & PV $(\mathbf{B U})$ & Trough $(\mathbf{B U})$ & BV $(\mathbf{B U})$ & FV $(\mathbf{B U})$ & SB $(\mathbf{B U})$ & PT $(\mathbf{m i n})$ & P. Temp. $\left({ }^{\circ} \mathbf{C}\right)$ \\
\hline Without treatment & $215 \pm 7.00^{\mathrm{a}}$ & $166 \pm 6.93^{\mathrm{a}}$ & $49 \pm 1.73^{\mathrm{a}}$ & $208 \pm 2.65^{\mathrm{a}}$ & $51 \pm 1.73^{\mathrm{a}}$ & $24.48 \pm 0.82^{\mathrm{a}}$ & $87.0 \pm 1.61^{\mathrm{a}}$ \\
\hline $\begin{array}{l}\text { PG autoclaving 15 min, } \\
\text { cooling 24 h }\end{array}$ & $70 \pm 1.73 \mathrm{~b}$ & $56 \pm 1.73^{\mathrm{b}}$ & $14 \pm 1.73^{\mathrm{bc}}$ & $79 \pm 2.65^{\mathrm{b}}$ & $24 \pm 1.00^{\mathrm{b}}$ & $25.00 \pm 1.94^{\mathrm{a}}$ & $87.4 \pm 1.14^{\mathrm{a}}$ \\
\hline $\begin{array}{l}\text { PG autoclaving 15 min, } \\
\text { cooling 48 h }\end{array}$ & $67 \pm 1.00^{\mathrm{c}}$ & $51 \pm 1.73^{\mathrm{c}}$ & $16 \pm 1.73^{\mathrm{b}}$ & $75 \pm 1.00^{\mathrm{c}}$ & $24 \pm 1.00^{\mathrm{b}}$ & $24.14 \pm 0.25^{\mathrm{a}}$ & $86.2 \pm 0.56^{\mathrm{a}}$ \\
\hline $\begin{array}{l}\text { PG autoclaving 15 min, } \\
\text { cooling 72 h }\end{array}$ & $67 \pm 2.00^{\mathrm{c}}$ & $51 \pm 1.00^{\mathrm{c}}$ & $16 \pm 1.00^{\mathrm{b}}$ & $75 \pm 1.00^{\mathrm{c}}$ & $25 \pm 1.00^{\mathrm{b}}$ & $24.18 \pm 1.25^{\mathrm{a}}$ & $86.4 \pm 1.14^{\mathrm{a}}$ \\
\hline $\begin{array}{l}\text { PG autoclaving 30 min, } \\
\text { cooling 24 h }\end{array}$ & $56 \pm 1.00^{\mathrm{d}}$ & $44 \pm 2.65^{\mathrm{d}}$ & $12 \pm 1.73^{\mathrm{c}}$ & $65 \pm 1.73^{\mathrm{d}}$ & $21 \pm 1.00^{\mathrm{c}}$ & $24.46 \pm 1.92^{\mathrm{a}}$ & $87.0 \pm 0.46^{\mathrm{a}}$ \\
\hline $\begin{array}{l}\text { PG autoclaving 30 min, } \\
\text { cooling 48 h }\end{array}$ & $49 \pm 1.00^{\mathrm{e}}$ & $39 \pm 2.65^{\mathrm{e}}$ & $10 \pm 1.73^{\mathrm{cd}}$ & $58 \pm 1.00^{\mathrm{e}}$ & $19 \pm 1.00^{\mathrm{d}}$ & $25.32 \pm 0.37^{\mathrm{a}}$ & $88.2 \pm 0.87^{\mathrm{a}}$ \\
\hline $\begin{array}{l}\text { PG autoclaving 30 min, } \\
\text { cooling 72 h }\end{array}$ & $42 \pm 2.65^{\mathrm{f}}$ & $34 \pm 2.00^{\mathrm{f}}$ & $8 \pm 1.00^{\mathrm{d}}$ & $51 \pm 1.00^{\mathrm{f}}$ & $17 \pm 1.00^{\mathrm{e}}$ & $25.32 \pm 1.29^{\mathrm{a}}$ & $87.9 \pm 0.50^{\mathrm{a}}$ \\
\hline
\end{tabular}

* $\mathrm{PV}=$ Peak viscosity, $\mathrm{BV}=$ Breakdown viscosity, FV = Final viscosity, $\mathrm{SB}=$ Setback, $\mathrm{PT}=\mathrm{Peak}$ time

P. temp. $=$ Peak temperature, $\mathrm{BU}=$ Brabender unit

* Values with the different superscript letters at the same column are significantly different $(\mathrm{P}<0.05)$ 


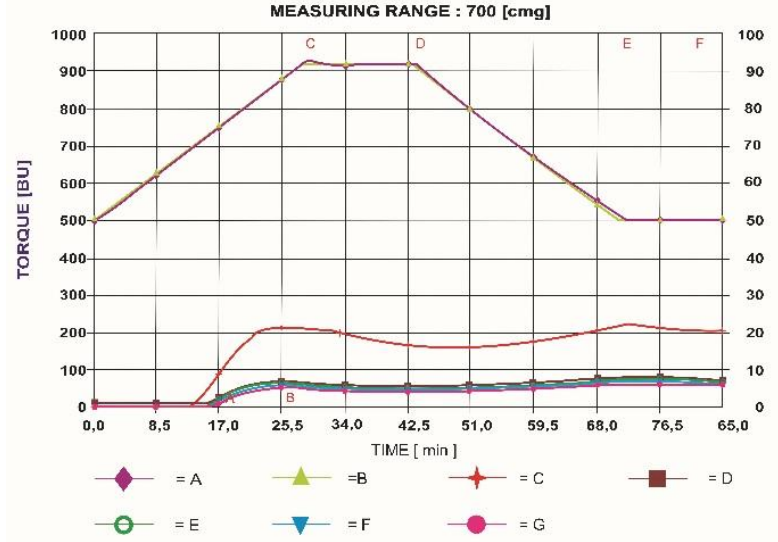

Figure-4. Amylographic profile of FCPF-based composite flour on various PG autoclaving and cooling time

( $\mathrm{A}=$ without treatment; $\mathrm{B}=\mathrm{PG}$ autoclaving $15 \mathrm{~min}$, cooling $24 \mathrm{~h} ; \mathrm{C}=\mathrm{PG}$ autoclaving $15 \mathrm{~min}$, cooling 48 h; D = PG autoclaving 15 min, cooling $72 \mathrm{~h} ; \mathrm{E}=\mathrm{PG}$ autoclaving $30 \mathrm{~min}$, cooling $24 \mathrm{~h} ; \mathrm{F}=\mathrm{PG}$ autoclaving $30 \mathrm{~min}$, cooling $48 \mathrm{~h} ; \mathrm{G}=\mathrm{PG}$ autoclaving $30 \mathrm{~min}$, cooling $72 \mathrm{~h}$ ).

\section{The degree of starch hydrolysis}

The degree of starch hydrolysis of FCPF-based composite flour on various PG autoclaving and cooling time is presented in Table 5.

The application of the PG autoclaving and cooling process was significantly $(\mathrm{P}<0.05)$ decreased the degree of starch hydrolysis of FCPF-based composite flour. FCPF-based composite flour with the lowest degree of hydrolysis was produced by PG autoclaving treatment $15 \mathrm{~min}$ and cooling $72 \mathrm{~h}$. These results indicated that the higher the RS content of FCPF-based composite flour (Table 2), the lower the degree of starch hydrolysis. This is consistent with Haralampu (2000) who reported that the formation of RS decreased the ability of starch to hydrolyze.

In general, the degree of starch hydrolysis of FCPF-based composite flour increased until the hydrolysis time of $120 \mathrm{~min}$ and no increase of degree of starch hydrolysis was observed started from min of 120 (Table 5).

\section{Estimated glycemic index (EGI)}

FCPF-based composite flour has a lower EGI value than reference food (Table 6), which is mainly due to high carbohydrate content in the form of dietary fiber (16.53\%). The results also showed that the autoclaving-cooling treatment would reduce the EGI value of FCPF-based composite flour from 75.02 to 59.94. Decrease in the EGI value of FCPF-based composite flour was strongly associated with the increase in RS content. The highest reduction in EGI value (59.94 \pm 0.11 ) occurred in the $15 \mathrm{~min}$ autoclaving and $72 \mathrm{~h}$ cooling treatment which also had the highest RS content $(7.31 \%)$ as previously mentioned in Table 2. According to Zheng et al. (2020), the autoclaving-cooling process will increase the RS content in rice grains reached $17.57 \%$ and decrease the EGI value from 78.35 to 66.08 .

Table-5. Degree of starch hydrolysis of FCPF-based composite flour on various PG autoclaving and cooling time at interval time $0-180$ min

\begin{tabular}{|l|c|c|c|c|c|c|c|}
\hline \multirow{2}{*}{ Treatment } & \multicolumn{6}{|c|}{ Starch hydrolyzed (\%) at interval (min) } \\
\cline { 2 - 7 } & $\mathbf{0}$ & $\mathbf{3 0}$ & $\mathbf{6 0}$ & $\mathbf{9 0}$ & $\mathbf{1 2 0}$ & $\mathbf{1 5 0}$ & $\mathbf{1 8 0}$ \\
\hline Without treatment & $0.01 \pm 0.01^{\mathrm{a}}$ & $46.62 \pm 0.87^{\mathrm{a}}$ & $48.34 \pm 0.75^{\mathrm{a}}$ & $47.42 \pm 0.44^{\mathrm{a}}$ & $46.38 \pm 0.70^{\mathrm{a}}$ & $47.65 \pm 1.15^{\mathrm{a}}$ & $48.62 \pm 0.38^{\mathrm{a}}$ \\
\hline $\begin{array}{l}\text { PG autoclaving 15 min, } \\
\text { cooling 24 h }\end{array}$ & $0.12 \pm 0.03^{\mathrm{a}}$ & $29.83 \pm 0.30^{\mathrm{b}}$ & $30.89 \pm 2.32^{\mathrm{b}}$ & $31.73 \pm 0.47^{\mathrm{b}}$ & $32.79 \pm 0.44^{\mathrm{b}}$ & $32.84 \pm 0.73^{\mathrm{b}}$ & $32.84 \pm 0.18^{\mathrm{b}}$ \\
\hline $\begin{array}{l}\text { PG autoclaving 15 min, } \\
\text { cooling 48 h }\end{array}$ & $0.05 \pm 0.04^{\mathrm{a}}$ & $27.21 \pm 1.57^{\mathrm{cd}}$ & $28.47 \pm 0.38^{\mathrm{bc}}$ & $28.62 \pm 0.03^{\mathrm{d}}$ & $30.08 \pm 0.37^{\mathrm{d}}$ & $30.30 \pm 0.62^{\mathrm{bc}}$ & $30.08 \pm 0.50^{\mathrm{d}}$ \\
\hline $\begin{array}{l}\text { PG autoclaving 15 min, } \\
\text { cooling 72 h }\end{array}$ & $0.03 \pm 0.03^{\mathrm{a}}$ & $25.48 \pm 1.04^{\mathrm{d}}$ & $25.84 \pm 0.66^{\mathrm{d}}$ & $27.36 \pm 1.15^{\mathrm{e}}$ & $27.85 \pm 0.77^{\mathrm{e}}$ & $28.48 \pm 0.58^{\mathrm{d}}$ & $28.46 \pm 0.87^{\mathrm{e}}$ \\
\hline $\begin{array}{l}\text { PG autoclaving 30 min, } \\
\text { cooling 24 h }\end{array}$ & $0.17 \pm 0.05^{\mathrm{a}}$ & $27.77 \pm 1.17^{\mathrm{bc}}$ & $29.37 \pm 1.47^{\mathrm{bc}}$ & $30.08 \pm 1.33^{\mathrm{c}}$ & $31.21 \pm 0.41^{\mathrm{c}}$ & $31.19 \pm 1.37^{\mathrm{bc}}$ & $31.43 \pm 0.27^{\mathrm{c}}$ \\
\hline $\begin{array}{l}\text { PG autoclaving 30 min, } \\
\text { cooling 48 h }\end{array}$ & $0.00 \pm 0.00^{\mathrm{a}}$ & $29.23 \pm 0.74^{\mathrm{bc}}$ & $30.03 \pm 0.79^{\mathrm{bc}}$ & $30.43 \pm 0.23^{\mathrm{bc}}$ & $31.46 \pm 0.31^{\mathrm{c}}$ & $31.38 \pm 0.13^{\mathrm{bc}}$ & $31.89 \pm 0.54^{\mathrm{c}}$ \\
\hline $\begin{array}{l}\text { PG autoclaving 30 min, } \\
\text { cooling 72 h }\end{array}$ & $0.02 \pm 0.01^{\mathrm{a}}$ & $29.44 \pm 0.39^{\mathrm{bc}}$ & $30.38 \pm 0.91^{\mathrm{bc}}$ & $31.41 \pm 0.46^{\mathrm{bc}}$ & $31.73 \pm 0.26^{\mathrm{c}}$ & $31.86 \pm 0.29^{\mathrm{b}}$ & $33.26 \pm 0.52^{\mathrm{b}}$ \\
\hline
\end{tabular}

Values with the different superscript letters at the same column are significantly different $(P<0.05)$ 
Table-6. AUC (area under curve), HI, and EGI of FCPF-based composite flour on various PG autoclaving and cooling time

\begin{tabular}{|l|c|c|c|}
\hline Sampel/Treatment & $\begin{array}{c}\text { AUC } \\
\text { (area under } \\
\text { curve) }\end{array}$ & HI & EGI \\
\hline $\begin{array}{l}\text { Ref. food (white } \\
\text { bread) }\end{array}$ & $12,151.56 \pm 24.68$ & $100.00 \pm 0.00$ & $94.61 \pm 0.00$ \\
\hline Without treatment & $7,815.75 \pm 20.43$ & $64.32 \pm 0.26$ & $75.02 \pm 0.14$ \\
\hline $\begin{array}{l}\text { PG autoclaving 15 } \\
\text { min, cooling 24 } \mathrm{h}\end{array}$ & $5,236.80 \pm 88.83$ & $43.10 \pm 0.78$ & $63.37 \pm 0.43$ \\
\hline $\begin{array}{l}\text { PG autoclaving 15 } \\
\text { min, cooling 48 } \mathrm{h}\end{array}$ & $4,792.35 \pm 48.47$ & $39.44 \pm 0.44$ & $61.36 \pm 0.24$ \\
\hline $\begin{array}{l}\text { PG autoclaving 15 } \\
\text { min, cooling 72 } \mathrm{h}\end{array}$ & $4,477.65 \pm 28.15$ & $36.85 \pm 0.20$ & $59.94 \pm 0.11$ \\
\hline $\begin{array}{l}\text { PG autoclaving } 30 \\
\text { min, cooling 24 } \mathrm{h}\end{array}$ & $4,962.60 \pm 94.21$ & $40.80 \pm 0.83$ & $62.13 \pm 0.46$ \\
\hline $\begin{array}{l}\text { PG autoclaving 30 } \\
\text { min, cooling 48 } \mathrm{h}\end{array}$ & $5,054.25 \pm 34.00$ & $41.59 \pm 0.25$ & $62.54 \pm 0.14$ \\
\hline $\begin{array}{l}\text { PG autoclaving 30 } \\
\text { min, cooling 72 } \mathrm{h}\end{array}$ & $5,143.80 \pm 22.73$ & $42.33 \pm 0.22$ & $62.95 \pm 0.12$ \\
\hline
\end{tabular}

\section{Conclusion}

PG autoclaving for 15 min and cooling time for $72 \mathrm{~h}$ is the optimal treatment which potentially increased the RS content of FCPF-based composite flour from $1.75 \%$ to $7.31 \%$. Increased the RS content changed in chemicals properties, granular morphology, polarized optical microscopy, amylographic profile, X-ray diffraction spectrum pattern and crystallinity; and lowering the degree of starch hydrolysis and estimated glycemic index (EGI) of FCPF-based composite flour. Increased the RS content would improve the functional properties of FCPF-based composite flour.

\section{Acknowledgement}

The authors would like to thanks to the Directorate of Research and Community Services, the Ministry of Research, Technology and Higher Education, Republic Indonesia, for funding this research through the scheme of Development Research in 2020.

Disclaimer: None.

Conflict of Interest: None.

Source of Funding: Directorate of Research and Community Services, the Ministry of Research and Technology, Republic of Indonesia..

\section{References}

Abioye VF, Adeyemi IA, Akinwande BA, Kulakow P and Maziya-Dixon B, 2017. Effect of steam cooking and storage time on the formation of resistant starch and functional properties of cassava starch. Cogent. Food Agric. 3: 1-11.

Abioye VF, Adeyemi IA, Akinwande BA, Kulakow P and Maziya-Dixon B, 2018. Effect of autoclaving on the formation of resistant starch from two Nigeria Cassava (Manihot esculenta) varieties. Food Res. 2(5): 468-473.

Ahvenainen P and Svedstrom K, 2016. Comparison of sample crystallinity determination methods by X-ray diffraction for challenging cellulose I materials. Cellulose. 23: 1073-1086.

Alsaffar AA, 2011. Effect of food processing on the resistant starch content of cereals and cereal products - a review. Int. J. Food Sci. Technol. 46: 455-462.

American Association of Cereal Chemists International (AACCI), 2010. Approved Methods of Analysis. Standard Method No: 32-40.01. The Association: St. Paul, MN, USA.

Ashraf S, Anjum FM, Nadeem M and Riaz A, 2012. Functional and technological aspects of resistant starch. Pak. J. Food Sci. 22(2): 90-95.

Błaszczak W, Bidzinska E, Dyrek K, Fornal J, Michalec $M$ and Wenda E, 2011. Effect of phosphorylation and pretreatment with high hydrostatic pressure on radical processes in maize starches with different amylose contents. Carbohydr. Polym. 85: 86-96.

Chen X, He X, Fu X and Huang Q, 2015. In vitro digestion and physicochemical properties of wheat starch/flour modified by heat-moisture treatment. J. Cereal Sci. 63:109-115.

Chung H, Lim HS and Lim S, 2006. Effect of partial gelatinization and retrogradation on the enzymatic digestion of waxy rice starch. J. Cereal Sci. 43: 353359.

Dundar AN and Gocmen D, 2013. Effects of autoclaving temperature and storing time on resistant starch formation and its functional and physicochemical properties. Carbohydr. Polym. 97: 764-771.

Englyst HN, Kingman SM and Cummings JH, 1992. Classification and measurement of nutritionally important starch fractions. Eur. J. Clin. Nutr. 46: S33-S50.

Fuentes-Zaragoza E, Sánchez-Zapata E, Sendra E, Sayas E, Navarro C, Fernández-Lõpez J and Pérez-Alvarez JA, 2011. Resistant starch as prebiotic: A review. Starch/Staerke. 63(7): 406-415.

Garcia-Ochoa F, Santos VE, Casas JA and Gomez E, 2000. Xanthan gum: production, recovery, and properties. Biotechnol. Adv. 18: 549-579. 
Goni I, Garcia-Alonso A and Saura-Calixto F, 1997. A Starch Hydrolysis Procedure to Estimate Glycemic Index. Nutr. Res. 17(3): 427-437.

Gunaratne A and Hoover R, 2002. Effect of heatmoisture treatment on the structure and physicochemical properties of tuber and root starches. Carbohydr. Polym. 49: 425-437.

Haralampu SG, 2000. Resistant starch - a review of the physical properties and biological impact of RS3. Carbohydr. Polym. 41(3): 285-292.

Herawati ERN, Ariani D, Nurhayati R, Miftakhussolikhah M, Na'imah $\mathrm{H}$ and Marsono $\mathrm{Y}$, 2019. Effect of Autoclaving-Cooling Treatments on Chemical Characteristic and Structure of Tacca (Tacca Leontopetaloides) Starch. Adv. Eng. Res. 194: 169-172.

Hidayat B, Hasanudin U, Akmal S and Muslihudin M, 2019. The growth dynamics, chemical, amylographic profile and granular morphology changes on cassava pulp fermentation. Asian J. Agric. Biol. 7(4): 617-623.

Hidayat B, Hasanudin U, Nurdjanah S, Yuliana N, Akmal S and Muslihudin M, 2020. Optimization of Characteristic of Fermented Cassava Bagasse FlourBased Composite Flour using Response Surface Methodology. Jurnal Aplikasi Teknologi Pangan. 9(3): 126-132.

Kim N, Kim J, Lee S, Lee H, Yoon J, Wang R and Yoo S, 2010. Combined effect of autoclaving-cooling and crosslinking treatments of normal corn starch on the resistant starch formation and physicochemical properties. Starch/Starke. 62: 358-363.

Ozturk S, Koksel H and Perry KWNg, 2011. Production of resistant starch from acid-modified amylotype starches with enhanced functional properties. J. Food Eng. 103(2): 156-164.

Putra INK, Suparthana IP and Ina NPT, 2020. Physicochemical properties and microstructure of the pregelatinized tannia flour prepared by a simple parboiling method. Asian J Agric \& Biol. 8(2): 138146.

Polesi LF and Sarmento SBS, 2011. Structural and physicochemical characterization of RS prepared using hydrolysis and heat treatments of chickpea starch. Starch/Starke. 63: 226-235.

Sun Q, Han Z, Wang L and Xiong L, 2014. Physicochemical differences between sorghum starch and sorghum flour modified by heat-moisture treatment. Food Chem. 145: 756-764.

Vatanasuchart N, Tungtrakul P, Wongkrajang $\mathrm{K}$ and Naivikul O, 2010. Properties of pullulanase debranched cassava starch and type-III resistant starch. Kasetsart J. (Nat. Sci.). 44: 131-141.

Vatanasuchart N, Niyomwit B and Wongkrajang K, 2012. Resistant starch content, in vitro starch digestibility and physico-chemical properties of flour and starch from Thai bananas. Maejo Int. J. Sci. Technol. 6(2): 259-271.

Vermeylen R, Goderis B and Delcour JA, 2006. An Xray study of hydrothermally treated potato starch. Carbohydr. Polym. 64: 364-375.

Wang S, Li C, Copeland L, Niu Q and Wang S, 2015. Starch Retrogradation: A Comprehensive Review. Compr. Rev. Food Sci. Food Saf. 14: 568-585.

Yamada Y, Hosoya S, Nishimura S, Tanaka T, Kajimoto Y, Nishimura A and Kajimoto O, 2005. Effect of bread containing resistant starch on postprandial blood glucose levels in humans. Biosci. Biotechnol. Biochem. 69(3): 559-566.

Yun SH and Matheson NK, 1990. Estimation of Amylose Content of Starches after Precipitation of Amylopectin by Concanavalin-A. Starch/Starke. 42: 302-305.

Zhang Y, Zeng H, Wang Y, Zeng S and Zeng B, 2014. Structural characteristics and crystalline properties of lotus seed resistant starch and its prebiotic effects. Food Chem. 155: 311-318.

Zheng Y, Wei Z, Zhang R, Deng Y, Tang X, Zhang Y, Liu G, Liu L, Wang J, Zhang M and Liao N, 2020. Optimization of the autoclave preparation process for improving resistant starch content in rice grains. Food Sci. Nutr. 2020. 00:1-12.

\section{Contribution of Authors}

Hidayat B: Contributed in experimental design and technical aspects and wrote manuscript

Hasanudin U, Nurdjanah S, Yuliana N \& Akmal S: Contributed in the technical aspects, data collection $\&$ analysis and manuscript write up

Muslihudin M: Conducted laboratory analysis and contributed in manuscript write up 